\title{
The Empathic Leader
}

\author{
Tímea Boda, PhD \\ János Neumann University, Business Faculty, Hungary
}

Doi: 10.19044/esj.2017.v13n29p51 URL:http://dx.doi.org/10.19044/esj.2017.v13n29p51

\begin{abstract}
Managers and their subordinates often have the same aims as their organisation: to be successful, to be content and to develop in a secure environment under good financial conditions. Still, we can often hear that workers do not feel comfortable, they do not have a good mood in their working places. They are not committed and they are not motivated - in such cases they are guaranteed to fail, and so is their organisation. In the operation of an organisation tight deadlines, hard work, not clearly defined functions and the feeling of not being understood result in role conflicts.

The task and the responsibility of a leader is to apply a communication culture that is based on honest interest towards his subordinates and on acceptance, that enables the avoidance of unnecessary tensions. Many managers consider active communication with and care of subordinate workers as an unnecessary activity and a sheer waste of time but the Pareto principle applies in this case as well. The empathetic leader is capable of realising his colleagues' competencies and accepting their personal aims and using them as a tool for the development of the organisation. The empathetic leader is capable to reach that workers experience the success of the organisation as their own success - this gives the organisation motivated and committed people.
\end{abstract}

Keywords: Empathy, leadership, motivation, communication

\section{Introduction}

In the past few decades, when the significance of knowledge capital and human capital has increased in organisational cultures, the management of tensions and workplace conflicts has become increasingly important. Managers had to learn how to handle such problems because internal tensions, being misunderstood, being neglected spoils the working atmosphere and that has a bad effect on the performance of the organisation. Often the manager himself is the cause of organisational problems, abnormal behaviour or deteriorating performance. Bad managerial communication habits, poor techniques, instructions, excessive control and autocratic 
management style are all factors that strengthen the problem. Often managerial behaviour itself expresses aggression. The manager assesses the performance of his staff, he may be very critical towards them what might arise fear from the part of his subordinates. Therefore a leader must primarily realize his own role in the development and the solution of workplace conflicts. If a leader is capable of accepting this, if he is capable of empathetic communication then he will be able to save both himself and his environment from unnecessary tensions.

\section{The influence of feelings, the control of the community}

Influencing feelings is a natural part of leadership. "Throughout history and in cultures everywhere, the leader in any human group has been the one to whom others look for assurance and clarity when facing uncertainty or threat, or when there's a job to be done. The leader acts as the group's emotional guide." (Goleman-Boyatzis - McKee, 2004).

The efficiency of an undertaking depends very much on the emotional quality of the workers that is how they feel themselves at their working place. Many researches have corroborated that a positive mood, work done with joy and happiness results in higher performance. One of the important tasks of a leader is to lay an emphasis to this and to guide collective emotions in a positive direction.

The invisible tie between a leader and his subordinate workers is responsible for the direction of emotions related to performance of the workers. If this points in a positive direction, it enables everyone to work according to their best abilities and knowledge. This is what we call resonance. If this turns negative, the leader creates dissonance what means that the leader cannot handle his own and his subordinate workers' emotions what leads to stress, anxiety and low efficiency.

Goleman states that we need to interact and communicate with others to develop our emotional security. This does not necessarily mean that my emotional security depends on what other people tell me; the non-verbal signs that mediate emotions have a much larger role. Metacommunication that gives real meaning to words mediates the essence of the information. What we are told we also feel. Intonation, speed, mimicry, posture has an effect on us. They seem to be truer than words.

A leader has aims, and his task is to control subordinate workers to reach this aim in a way that makes them happy and satisfied. Therefore it is important that they identify themselves with the leader's emotions and that the leader can communicate with a high-level emotional intelligence for this to work in a natural way without a need for persuasion or influence.

It has been observed among people who work together closely that the emotionally most expressive person reflects his mood on the others 
without saying a word. They "catch" each other's mood in the office and this reflects in their work (Goleman et al, 2003).

It is thus also important for a leader to be able to sense who the most expressive workers are, who emotionally influence the other workers. If he manages to do this, he will be able to influence these workers in a positive way and they will draw the others with them. But a leader would have to possess high-level empathy to be able to accomplish that. This is particularly important because, according to Goleman et al if this does not work from the part of the leader, if his communication is not credible then the team will "nominate" itself a non-official, de facto leader whom they trust (Goleman et al 2003).

This can be dangerous for the real leader because he will not only loose his respect but he will be less capable of gaining his subordinate workers support to reach his aims. He may meet resistance and might spend most of his time fighting this resistance instead of working on creative tasks. Many researches prove that most of job fluctuations depend on the leader. A resonant, empathetic leader, who at the same time is respected because of his proficiency, with whom it is a good experience to work together with, who creates a good workplace atmosphere will cause lower fluctuation. This is particularly important in a difficult economic situation or in a negative business environment when the strength of the community and the emotional relation to co-workers, the leader and the company form the primary basis of survival. Smiling employees attract smiling clients and that increases income.

Emotional self-regulation is essential for a leader. Among/from the areas of emotional intelligence and competencies Goleman emphasises also the role of one of the social competencies: empathy.

Social competencies are competencies that play a role in controlling our social relations. Empathy is one of the social competencies. According to Goleman, empathy is the ability to experience, understand and respect other people's emotions and viewpoints, the responsiveness for all these (Goleman et al, 2003).

Empathy in another aspect is "The experience of what other people think, the competence to accept their perspectives and the willingness to contact and harmonise with a wide variety of people." (Borgulya, Somogyvári, 2007.)

We can distinguish three levels of empathy:

1. Foundation level: one is capable of reading in other people's emotions.

2. Higher level: one is capable of reacting to another person's unexpressed worries, emotional attitudes. 
3. Highest level: with empathy one is capable of understanding problems that are in the background of other people's emotional life. What kind of emotions does the other person experience and how does this impact his communication?

The empathetic leader is practically able to decode and understand other person's non-verbal communication. He may also understand what kind of effect he has on others, because for example a co-worker's nonverbal manifestations signal to what extent he accepts him, what his emotional manifestation is in the given situation. This is important for a leader because subordinate workers are inclined to agree with and praise a leader also when they disagree (Levenson - Ruef, 1997) This is a selfdefence reaction that may poison work and if a leader does not explore true emotional attitudes, authoritarian leadership may develop. There are many cases when e.g. in a meeting one defends his standpoint in a matter aggressively. But the problem is not that the necessity of the project is questioned but one expresses his feelings about not being able to or not being prepared to do the job or is being overloaded and because of these feelings he reacts in an offensive way to the leader's communication. The emotionally intelligent leader should feel this duality and explore the true emotions and feelings about the situation. This kind of attitude results in much more success than neglecting true emotional attitude because of not understanding co-workers and further arousing tensions in colleagues.

There are leaders who suppress their emotional messages about their fellow workers' because then they have to care less about others. They think that this way they can save time and energy. This behaviour does not bring results because they will seem to be a rigid and uppish leader in the eyes of his colleagues, even if they are not. These leaders think that a strict, authoritarian style is more effective (Zsoldos, 2007).

Many workers and managers still have the view that a manager should be arrogant, brooks no contradiction, forces his will on everyone and subordinates must adjust to all this with more or less success and conflicts. According to a study from the W. P. Carey School of Business at Arizona State University, where researchers interviewed managers of 63 big Chinese private firms shows humble, understanding and supporting CEOs significantly benefit a company and its management. Humble CEOs are more open to joint decisions and that improves the efficiency of the company. "Their behavior positively affects both top and middle managers, who then exhibit higher commitment, work engagement, job satisfaction and job performance." - says professor Angelo Kinicki. "They are more willing to seek feedback about themselves, more empathetic and appreciative of others' strengths and weaknesses, and more focused on the greater good and others' welfare than on themselves." According to the professor leadership 
behaviour acts as an example and it normally cascades downward in the organisation and effects just about everyone at a company. (Kinicki et al, 2014).

Kohlrieser calls this kind of empathetic leader attitude creating "emotional bonds". According to the professor the power of bond-creating is that relations between leaders and co-workers become personal and that "detoxifies" the process. He also considers this to be a leader's impotence (Kohlrieser, 2007).

With the help of creating bonds the parties gain a clear picture during communication. This process is helped by the following qualities: fast perception, fast analytical skills and fast reactivity.

According to Kohlrieser authentic communication requires the following four competencies:

1. Perception: listen to the words and body language, take in the message.

2. Interpretation: decode the message into thoughts, attach meaning to the expressions. The body, emotions, the intellect and the mind take part in the process.

3. Evaluation: understanding and evaluating the message.

4. Response: the recipient signals with verbal and non-verbal communication that he has received the message and is ready to reply.

A difference must be made between passive and active listening. In the case of passive listening one does not truly pay attention, emotions move apart thus empathy cannot operate properly in the given situation (Kohlrieser, 2007.)

To be able to understand the real content of messages it is important for the leader to learn the technique of active listening. The active listener makes efforts to open the other person and avoids behaviour that triggers isolation and that leads to the end of the communication process (Borgulya, 2007).

In a well-functioning, harmonic discussion the leader pays attention to his partner's and his own non-verbal signs. For the sake of creating a common atmosphere and to become one it is necessary to take over the partner's posture and his way of sitting. Urging leads to the end of communication because it sends the message "It is not important to me what you are saying, I do not have time for you". A little investment of time pays off for the leader because untreated tensions will lead to bigger problems later.

The two fundamental techniques of active listening are the following: 1. Summarizing: from time-to-time you summarize what your partner has said. E.g. If I understand you well you think that... 
2. Reflecting emotions: you tune yourself to your partner's emotions and you reflect them in respect to the topic. E.g. I see you are unhappy about... 2013).

Both simple techniques help to understand each other (Gordon,

"If a leader understands a person in trouble he also gets a key to influence and control him, he can avoid conflicts and unpleasant reactions..." (Buda, 2006).

In case of managers superordination itself may be a barrier to empathy because a manager has various tools to resolve a conflict. In uneven relations, like a manager-subordinate relation, the subordinate worker seldom dares to show true emotions. This can result in hidden tensions within the organisation and that leads to low effectiveness and low motivation. Researches show that especially authoritarian management is what switches off interpersonal feedback and weakens empathy because impersonality, excessive rationality and the restriction of communication opportunities of co-workers form part of an authoritarian management style. Authoritarian managers do not receive critical feedback from their staff, thus they block the development of their skills to understand co-workers. Experience shows that this kind of management communication worsens as time passes (Buda, 2006).

The significance of democratic management became important especially in the past few decades when numerous studies proved the advantages of democratic leadership. The role of the human factor, human capital and know-how has increased, thus controlling them has become a key factor. An organisation operates effectively if not only the leader, but also subordinate co-workers feel engaged, if they have bondages within the organisation. Organisation psychology calls this "involvement". It is thus particularly significant for a manager to be able to promote this process to become an empathetic, democratic leader.

\section{Conclusion}

The success of a leader and his organisation depends not only on professional knowledge but also on the emotional attitude of the leader. Only a very charismatic, devoted leader is capable of excellent performance and achieve that his co-workers are successful as well. This requires constant self-development and the development of co-workers as well. Motivation and commitment are key issues in our days. Employees are committed if they are acknowledged, if they are led and supported, if they get honest attention. This requires an empathetic leader who listens to others. Coworkers need special attention when there is big pressure on them in order to constantly increase their performance. The empathetic leader is able to 
recognize his co-workers' strengths and competencies and thereby can specify roles within the organisation - that leads to successful teamwork and an innovative organisation that reacts fast to challenges.

\section{References:}

1. Borgulya, Ágnes \& Somogyvári, Márta (2007). Kommunikáció az üzleti világban. Budapest: Akadémiai Kiadó

2. Buda, Béla (2006): Empátia. Budapest: Urbis Könyvkiadó

3. Goleman, Daniel \& Boyatzis, Richard \& McKee, Annie (2004). Primal Leadership: Learning to Lead with Emotional Intelligence. Cambridge, MA: Harvard Business School Press

4. http://www.centerforcommunityleadership.com/static/centerforcomm unityleadership/newsletter.php?file=/centerforcommunityleadership/n ewsletter/1-20.php, Accessed 06042016

5. Goleman, Daniel \& Boyatzis, Richard \& McKee, Annie (2003). A természetes vezetö. Budapest: Vince Kiadó

6. Gordon, Thomas \& Bruch, Noel (2003). Emberi kapcsolatok. Gordon Kiadó Magyarország Kft.

7. Kinikci, Angelo et al (2014). Humble Chief Executive Officers'Connections to Top Management Team Integration and Middle Managers' Responses. Administrative Science Quarterly 59 (2014), Cornwell University http://asq.sagepub.com/content/59/1/34.full.pdf+html, Accessed: 10 062016

8. Kohlrieser George (2007). Túszok a tárgyalóasztalnál. Budapest: Háttér Kiadó

9. Levenson, R. W. \& Ruef. A. M. (1997). Physiological aspects of emotional knowledge and rapport. Empathic Acuracy. New York: Guilford Press

10. Zsoldos Benő (2007). Társas kapcsolataink és kezelésük a munkahelyen. Magyar Grafika 2007/1. 